\title{
Ewing's tumours and neuroblastomas
}

\author{
H. B. MARSDEN AND J. K. STEWARD \\ From the Royal Manchester Children's Hospital and the Departments of \\ Child Health and Pathology, University of Manchester
}

SYNOPSIS From a study of 59 cases of neuroblastoma and 21 patients classified as cases of Ewing's tumour there appear to be differences in age incidence, duration of disease, gross and microscopical appearance, and metastatic spread. The normal rate of excretion of catecholamines by patients with Ewing's tumour is an additional differentiating feature.

James Ewing (1922) selected a small-celled, nonosteogenic tumour of bone with a number of clinical features, including slow rate of growth, and classified it as endothelial myeloma or diffuse endothelioma of bone. All the patients in his series were under 21 years of age and seven of the 10 cases showed tumours in the long bones of the limbs.

The difficulty of diagnosing such a tumour on histological grounds, in particular when only a small biopsy fragment is obtained, has led to confusion between Ewing's tumour and metastatic neuroblastoma in bone. It was therefore decided to compare the findings in such cases included in the Manchester University Children's Tumour Register during the period September 1953 to September 1962. Twenty-one children with Ewing's tumour and 59 with neuroblastoma were studied. Seventeen of those with Ewing's tumour have died with recurrence of the growth and one is moribund. Fifty of the children with neuroblastoma have died; in 44 of them the tumour was the cause of death, while the remaining six succumbed from non-neoplastic causes. Necropsies were performed in seven cases of Ewing's tumour and in 33 cases of neuroblastoma.

In all the cases of Ewing's tumour a single bone lesion presented and in over $60 \%$ of the patients there was no other evidence of tumour for more than a year. In three patients in whom a cure may be hoped for, no further tumour has developed even up to six years after the primary was detected. The site of initial bone involvement in the 21 cases is shown in Table I.

The development of a bone deposit in the neuroblastoma cases was rapidly followed by others, frequent sites being the skull or neck of the femur. This multiple bone involvement was present in 28 out of the 30 cases with osseous metastases in this series.

The neuroblastoma arises from cells which migrate
TABLE I

\begin{tabular}{lr}
$\begin{array}{c}\text { PRIMARY SITE IN EWING'S TUMOUR } \\
\text { Site }\end{array}$ & No. of Cases \\
\hline Femur & 4 \\
Tibia & 4 \\
Humerus & 4 \\
Fibula & 3 \\
Pelvis & 2 \\
Rib & 2 \\
Ulna & 1 \\
Vertebra & 1 \\
Total & 21
\end{tabular}

from the neural crest to form the sympathetic ganglia and adrenal medulla. A tumour mass was detected in the paravertebral or pararenal regions in all the cases of neuroblastoma. In only four of the 21 children with Ewing's tumour was a mass detectable in these regions and in two of them these masses were apparent so long after the original bone lesions that it seemed likely that they were metastases.

\section{AGE INCIDENCE}

The patients with neuroblastoma were younger than those with Ewing's tumour (Table II). There was no case of the latter in the first two years of life whereas neuroblastomas were most frequently encountered in this age period.

\section{COURSE OF DISEASE}

The progression of disease in the cases of Ewing's tumour was slower than in those of neuroblastoma, $90 \%$ of the fatal cases living for more than one year after clinical onset, whereas $90 \%$ of the patients dying from neuroblastoma lived for less than one year. Even more striking was the duration of disease in fatal cases of Ewing's tumour when compared with neuroblastoma showing evidence of bone metastases (Table III). 
TABLE II

AGE AT CLINICAL ONSET

\begin{tabular}{|c|c|c|c|c|c|c|c|c|c|c|c|c|c|c|c|}
\hline & \multicolumn{15}{|c|}{ Age at Onset (yr.) } \\
\hline & -1 & -2 & -3 & -4 & -5 & -6 & -7 & -8 & -9 & -10 & -11 & -12 & -13 & -14 & -15 \\
\hline $\begin{array}{l}\text { Neuroblastoma } \\
\text { Ewing's tumour }\end{array}$ & $\begin{array}{r}13 \\
0\end{array}$ & $\begin{array}{r}10 \\
0\end{array}$ & $\begin{array}{l}6 \\
1\end{array}$ & $\begin{array}{l}6 \\
2\end{array}$ & $\begin{array}{l}4 \\
1\end{array}$ & $\begin{array}{l}1 \\
2\end{array}$ & $\begin{array}{l}5 \\
4\end{array}$ & $\begin{array}{l}3 \\
1\end{array}$ & $\begin{array}{l}1 \\
1\end{array}$ & $\begin{array}{l}0 \\
1\end{array}$ & $\begin{array}{l}\mathbf{0} \\
\mathbf{3}\end{array}$ & $\begin{array}{l}1 \\
0\end{array}$ & $\begin{array}{l}2 \\
1\end{array}$ & $\begin{array}{l}\mathbf{0} \\
\mathbf{3}\end{array}$ & $\begin{array}{l}1 \\
1\end{array}$ \\
\hline
\end{tabular}

TABLE III

TIME FROM FIRST BONE LESION TO DEATH

\begin{tabular}{|c|c|c|c|c|c|c|c|c|c|c|c|c|}
\hline & Time & Firs & e Lesi & Dea & th.) & & & & & & & \\
\hline & -3 & -6 & -9 & -12 & -15 & -18 & -21 & -24 & -27 & -30 & -33 & -360 \\
\hline $\begin{array}{l}\text { Neuroblastoma } \\
\text { Ewing's tumour }\end{array}$ & $\begin{array}{l}8 \\
0\end{array}$ & $\begin{array}{r}14 \\
0\end{array}$ & $\begin{array}{l}5 \\
1\end{array}$ & $\begin{array}{l}2 \\
1\end{array}$ & $\begin{array}{l}1 \\
5\end{array}$ & $\begin{array}{l}0 \\
3\end{array}$ & $\begin{array}{l}0 \\
1\end{array}$ & $\begin{array}{l}0 \\
0\end{array}$ & $\begin{array}{l}0 \\
2\end{array}$ & $\begin{array}{l}0 \\
0\end{array}$ & $\begin{array}{l}0 \\
1\end{array}$ & $\begin{array}{l}0 \\
\mathbf{3}\end{array}$ \\
\hline
\end{tabular}

GROSS APPEARANCE

The Ewing's tumours appeared to be rather firm and white to the naked eye and showed extensive invasion of the surrounding tissues while, at the same time, only involving the medullary cavity to a limited extent (Fig. 1). The neuroblastoma in bone was, by comparison, red and vascular with scattered involvement of the marrow space, becoming confluent and showing intracortical and subperiosteal extension (Fig. 2). The extensive medullary invasion accounts for the frequency with which neuroblastoma tumour cells may be detected in aspirated samples.

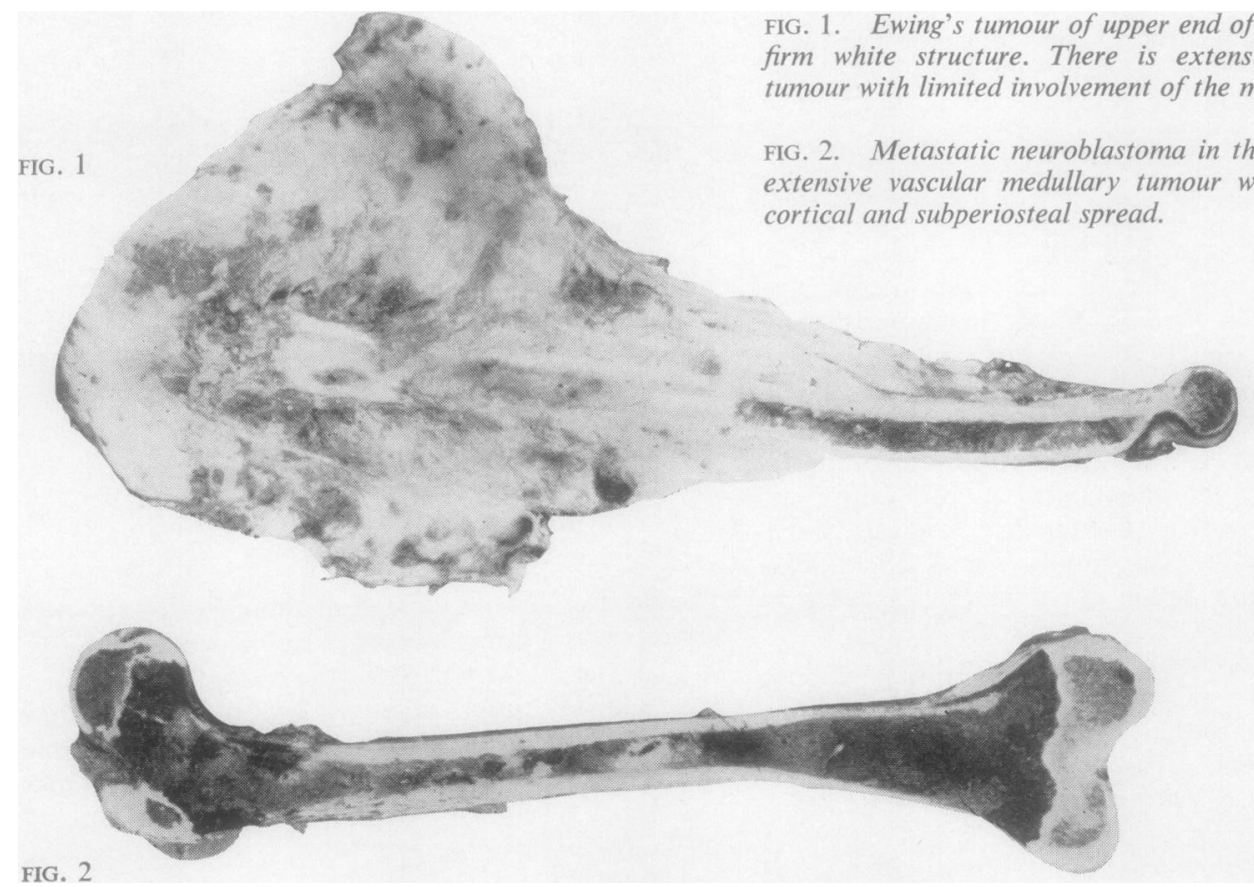
eliminate error.

The sites of metastasis in both tumours are compared in Table IV. The figures given are not intended to ${ }_{\subseteq}$ be completely accurate as adequate post-mortem examination was only carried out in half the fatal $\vec{\oplus}$ cases, but radiographs of the chest and post-mortem skeletal surveys were undertaken in an attempt to

Spread to bone was the most frequently encountered metastatic site in the neuroblastoman cases. However, as stated above, one deposit was rapidly followed by others, while the subsequent

FIG. 1. Ewing's tumour of upper end of humerus showing firm white structure. There is extensive extra-osseous tullary cavity mour with limited intra 
TABLE IV

METASTASES

\begin{tabular}{lcc} 
Site & Neuroblastoma (\%) & Ewing's \\
\hline Bone & 50 & 38 \\
Lymph node & 42 & 14 \\
Liver & 24 & 5 \\
Lung & 13 & 71
\end{tabular}

bone lesions in Ewing's tumour developed after a longer interval and were relatively few in number.

Lymph nodes were the second most frequent site of secondary involvement encountered in neuroblastoma whereas this could seldom be detected in the patients with Ewing's tumour. This feature has been remarked upon by Lichtenstein (1959).

Liver involvement could not be excluded in patients dying without post-mortem examination, but in only one such examination in a case of Ewing's tumour could a liver deposit be detected. Hepatic invasion was relatively frequent in neuroblastoma. No example of widespread liver invasion was seen in any case of Ewing's tumour such as may be found in the so-called Pepper syndrome (Pepper, 1901).

Spread to the lungs was the most frequently encountered site of metastasis in the cases of Ewing's tumour. The deposits were multiple, subpleural and intrapulmonary, and could sometimes be readily separated from the surrounding lung parenchyma (Fig. 3). Some of the cases of neuroblastoma showing lung involvement were probably due to direct extension of a paravertebral thoracic tumour rather than examples of metastatic deposition.

\section{MICROSCOPIC APPEARANCES}

The neuroblastomas possessed a number of distinguishing features which were not present in the Ewing's tumours. The most frequent finding was the presence of eosinophilic fibrillary material (Fig. 4) which was detected in $80 \%$ of the specimens of neur oblastorra subjected to histological examination. A very definite lobular arrangement was seen in the majority of tumours with thin septa between groups of cells which were sometimes clustered along one edge of the lobule (Fig. 5). Evidence of maturation toward the neurone was detected in about one half of the specimens and even tumours which were, for the most part, undifferentiated showed occasional examples of nuclear enlargement, increased prominence of nucleoli. and development of cytoplasm (Fig. 6). Calcification (Fig. 7) was the next most frequent finding whereas typical rosettes were only seen in rather more than one third of tumours (Fig. 8). Giant cells with pleomorphic nuclei were occasionally seen in specimens in which fibrillary material and lobular arrangement were features (Fig. 9).

The Ewing's tumours were more uniform and groups of cells were frequently separated by broad bands of fibrous tissue indicating the slow rate of growth and evidence of tissue reaction (Fig. 10).

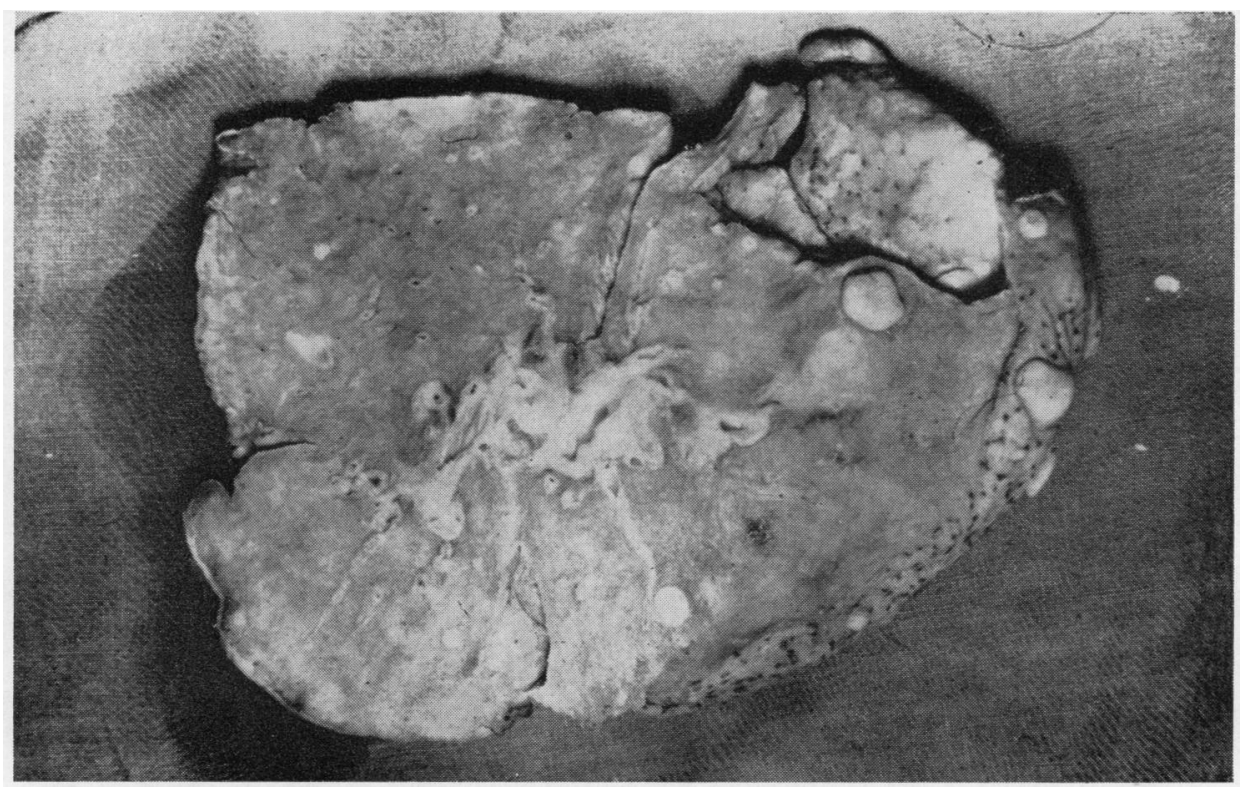

FIG. 3. Metastatic pulmonary deposits in Ewing's tumour. 
FIG. 4. Neuroblastoma showing eosinophilic fibrillary web. Haematoxylin and eosin $\times 1,250$.
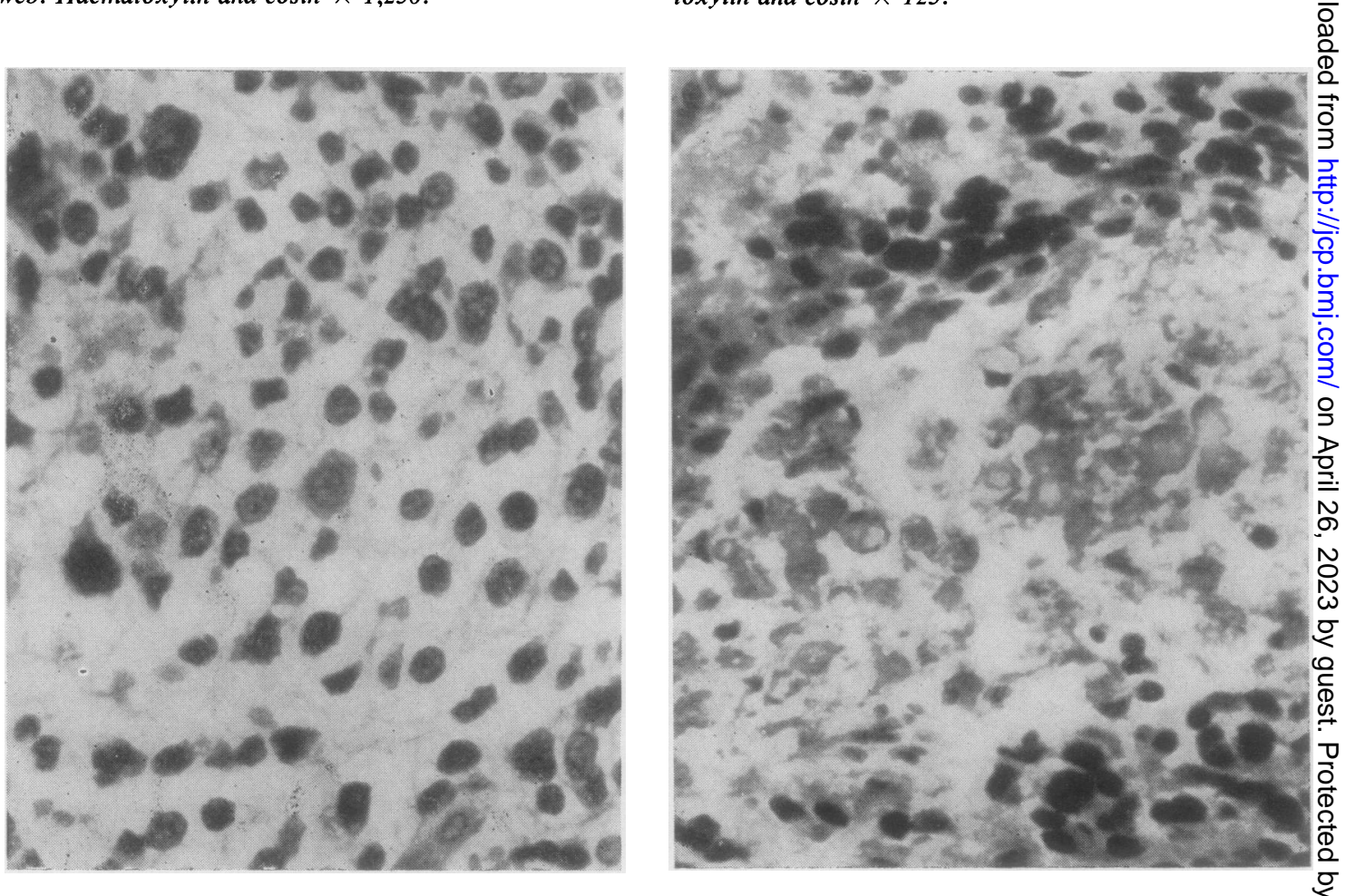

FIG. 5. Lobular arrangement in neuroblastoma. Haematoxylin and eosin $\times 125$.

FIG. 6. Maturation towards the neurone in neuroblastoma. Haematoxylin and eosin $\times 500$.

FIG. 7. Calcification
and eosin $\times 500$. lin 


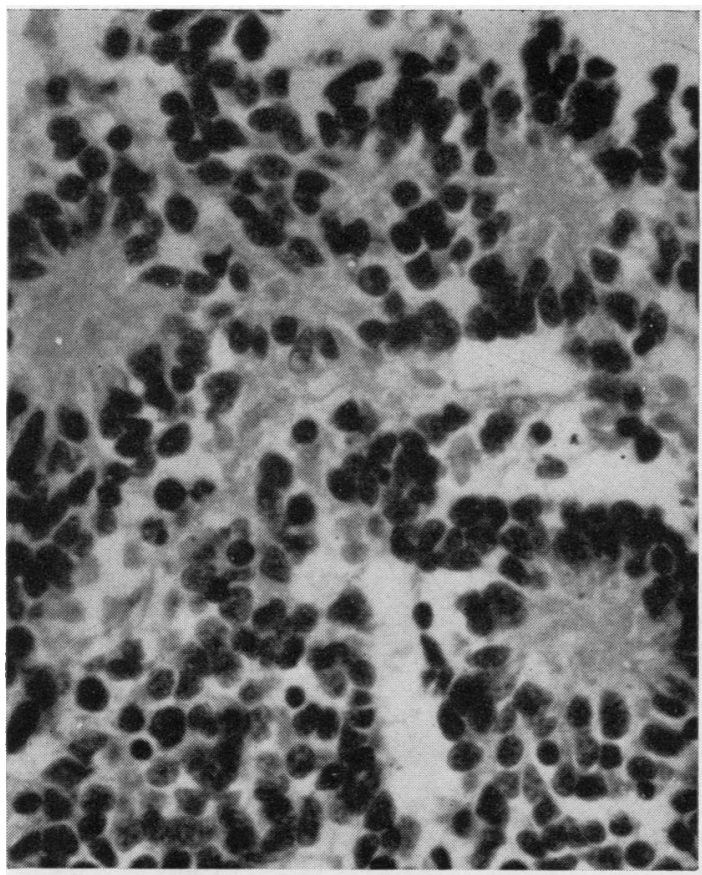

FIG. 8. Neuroblastoma with rosettes. Haematoxylin and eosin $\times 500$

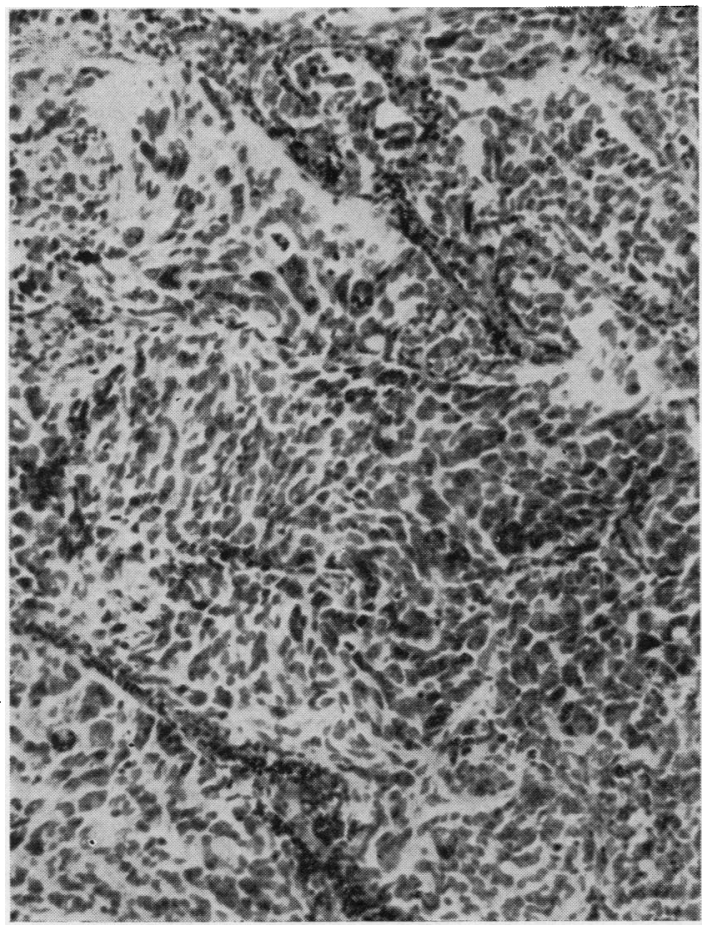

FIG. 9. Giant cell formation in neuroblastoma with preservation of lobular arrangement. Haematoxylin and eosin $\times 125$.

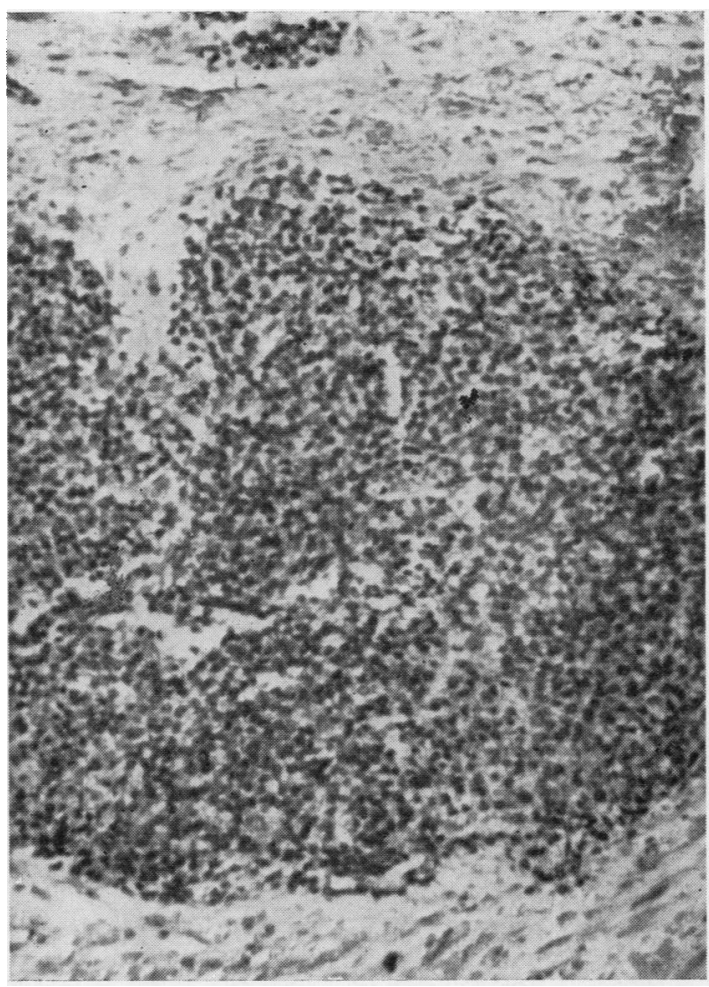

FIG. 10. Ewing's tumour showing uniform small cells with fibrous reaction. Haematoxylin and eosin $\times 125$.

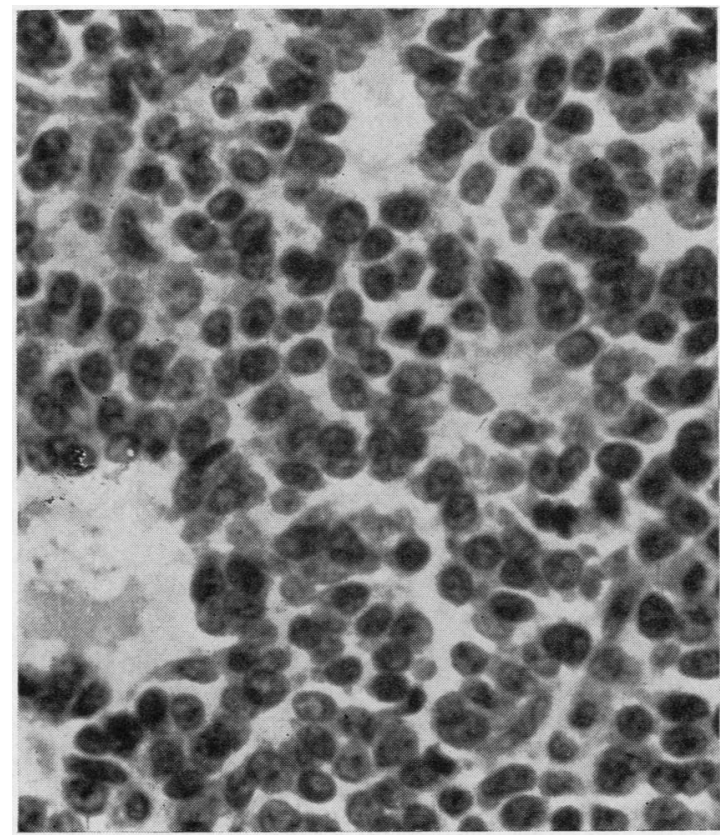

FIG. 11. Ewing's tumour with endothelial appearance due to liquefaction of tissue. Haematoxylin and eosin $\times 500$. 


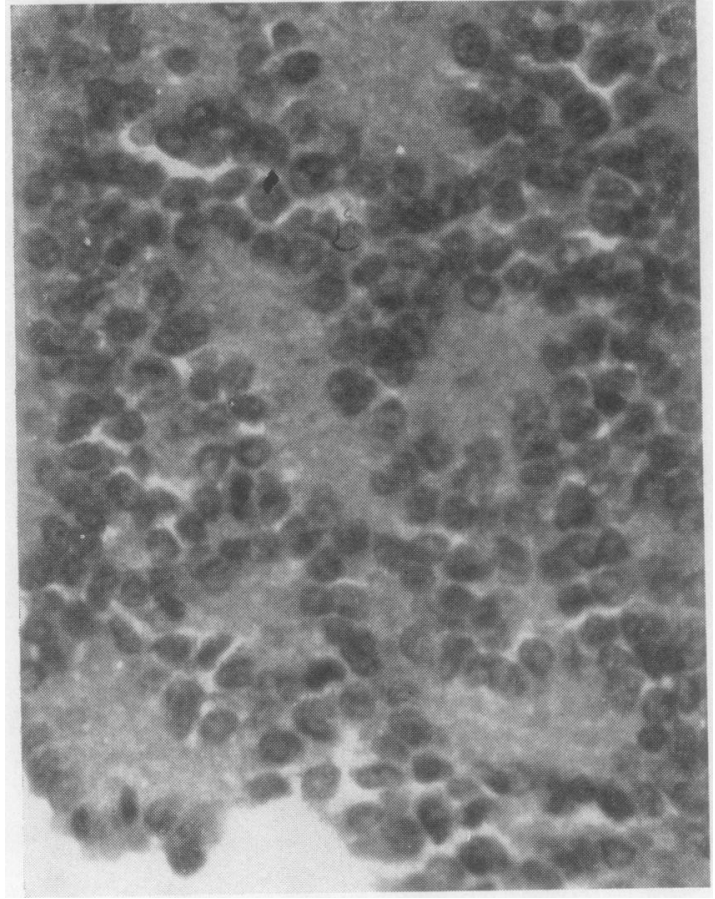

FIG. 12. Imperfect rosettes in Ewing's tumour with grouping of cells around trabeculae. Haematoxylin and eosin $\times 500$.

True endothelial spaces were not seen, although their presence was occasionally suggested, and it was considered that this was the result of degeneration and liquefaction of tumour tissue (Fig. 11). The grouping of cells along fibrous trabeculae was thought to account for the rather ill-defined rosette arrangement (Fig. 12). In bone deposits the cells were closely packed with only a small rim of cytoplasm occasionally detected but in metastases in soft tissue a variable amount of eosinophilic cytoplasm was more readily visible (Fig. 13).

\section{BIOCHEMICAL FEATURES}

Following the report of increased excretion of pressor amines in a patient with neuroblastoma (Mason, Hart-Mercer, Millar, Strang, and Wynne, 1957), the urinary increase of catecholamines and their metabolites has been well established and the subject is reviewed by Bell (1963). The demonstration in neuroblastoma sections that tumour cells produce catecholamine has been suggested by chromate fixation and Leishman staining (Marsden, 1963).

It is difficult to assess the proportion of neuroblastomas with positive results from an examination of the literature. Williams and Greer (1963) collected

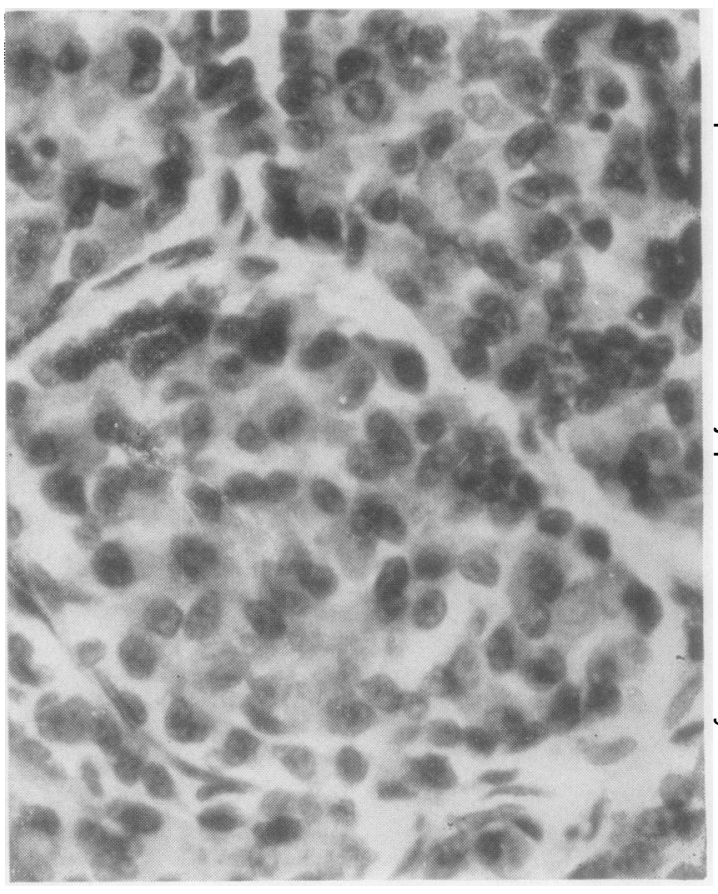

FIG. 13. Metastatic Ewing's tumour in lung showing $\overline{\bar{O}}$ presence of more abundant eosinophilic cytoplasm. ํํํ Haematoxylin and eosin $\times 500$.

40 positive results from 42 cases $(95 \%)$ when homovanillic and vannilylmandelic acids were estimated Voorhess, Pickett, and Gardner (1963) have reported negative findings in five out of 26 cases? subjected to a more detailed chemical investigation.

In this series, when all the metabolites of D.O.P.A. have been estimated, 17 cases of neuroblastoma haveo shown increased excretion and a negative result has $₹$ not yet been encountered in the presence of activeo tumour. In three of the patients the tests became negative after treatment of the tumour.

Eleven patients with Ewing's tumour were examined biochemically and showed no evidence of increased excretion of catecholamines or their 0 metabolites. Five of the patients had commenced N treatment, although in some cases this was justo before examination of the urine. In the remainingo six patients there was extensive and active tumour present.

In conclusion, it would appear from this study thato there is a slowly growing, small-celled tumouro occurring predominantly in the long bones of young subjects which metastasizes particularly to the lungs and other bones. The endothelial nature of sucho tumours was not evident in the material examined and Ewing in his later life had considerable doubô 


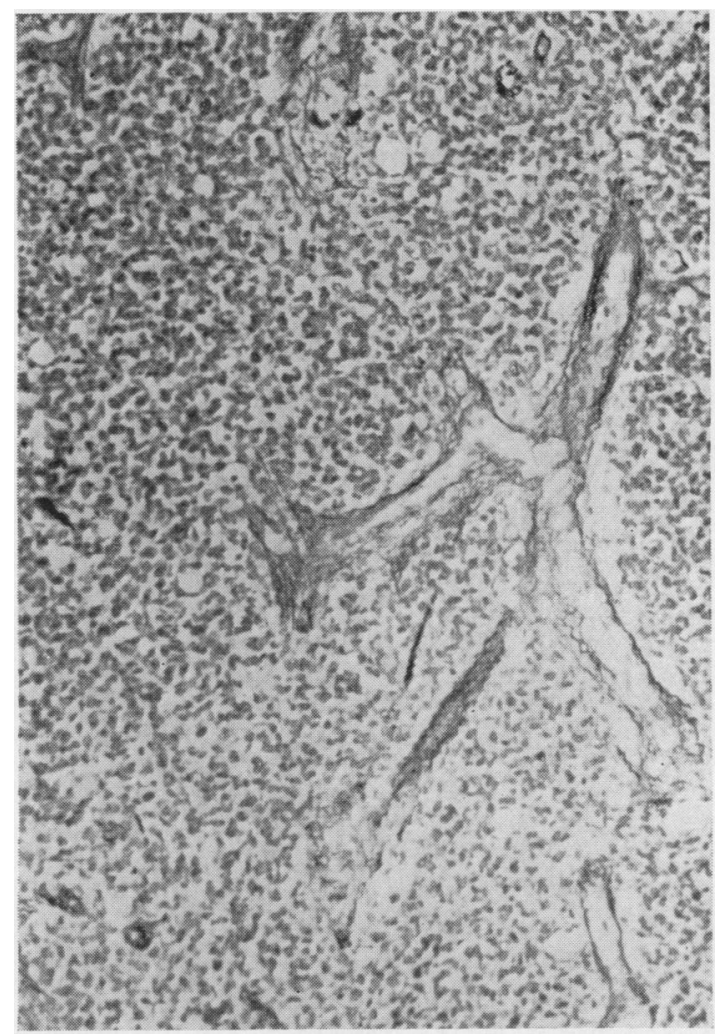

FIG. 14. Ewing's tumour showing reticulin confined to vascular sepia. Gomori $\times 125$.

concerning this aspect. In addition, in our series the tumour did not disseminate or extend widely through the marrow cavity.
In the sections studied, the reticulin in the Ewing's tumour was confined to the vascular septa with no penetration of cell groups (Fig. 14), thus differing from the reticulum cell sarcoma of bone as described by Parker and Jackson (1939). In addition the reticulum cell sarcomas tended to metastasize to lymph nodes and have a reasonably good prognosis. For these reasons, and to avoid speculation about the tissue of origin, the term 'Ewing's tumour' has been used throughout this paper.

The precise nature of Ewing's tumour must await further study, but there appear to be several features distinguishing it from metastatic neuroblastoma in bone.

We are grateful to Professor A. C. P. Campbell and Professor Wilfrid Gaisford for their interest in this work, to the members of, and contributors to, the Manchester University Children's Tumour Registry, and to Miss E. M. Hammond and Mr. M. Bell for a great deal of biochemical assistance.

\section{REFERENCES}

Bell, M. (1963.) In The Clinical Chemistry of Monoamines, p. 82. Elsevier, Amsterdam.

Ewing, J. (1922). Arch. Surg., 4, 485.

Lichtenstein, L. (1959). In Bone Tumors, 2nd ed., p. 239. Mosby, St. Louis.

Marsden, H. B. (1963). In The Clinical Chemistry of Monoamines, p. 76. Elsevier, Amsterdam.

Mason, G. A., Hart-Mercer, J., Millar, E. J., Strang, L. B., and Wynne, N. A. (1957). Lancet, 2, 322.

Parker, F. Jr., and Jackson, H. Jr. (1939). Surg. Gynec. Obstet., 68, 45.

Pepper, W. (1901). Amer. J. med. Sci., 121, 287.

Voorhess, M. L., Pickett, L. K., and Gardner, L. I. (1963). Amer. J. Surg., 106, 33.

Williams, C. M., and Greer, M. (1963). J. Amer. med. Ass., 183, 836 